Jurnal Riset Kesehatan, 9 (1), 2020, 6 - 11
DOI: 10.31983/jrk.v9i1.4953
Jurnal Riset Kesehatan
http://ejournal.poltekkes-smg.ac.id/ojs/index.php/jrk

\title{
THE EFFECT OF KAFFIR LIME (CITRUS HYSTRIX) ESSENTIAL OIL ON BEHAVIOR AND MORTALITY OF Aedes aegypti LARVAE
}

\author{
Ririh Jatmi Wikandaria*) ; Surati ${ }^{\mathrm{b}}$ \\ a,b Jurusan Analis Kesehatan ; Poltekkes Kemenkes Semarang, \\ Jl. Wolter Monginsidi No. 115, Pedurungan Tengah, Pedurungan, Kota Semarang, Indonesia
}

\begin{abstract}
DHF vector control still uses chemicals. Long-term application can lead to target insect resistance and environmental pollution so that a better alternative is to use biological insecticides because it is environmentally friendly. The aim of the study is to identify the effect of kaffir lime peel essential oil on the behavior and mortality of Ae.aegypti larvae. The research method used was completely randomized design of three treatments and three replications. The results show that larval behavior after administration of kaffir lime peel essential oil at a concentration of $10^{3} \mathrm{ppm}$ decreased the frequency of movement, the larvae were unable to rise to the surface of the water after 1.5 hours. The results of the research were tested with probit analysis at a confidence level of 95\% LD 263,552 ppm. The analysis result in one-way ANOVA for the number of differences in the number of dead larvaes, with the value obtained sig. $=0.000$, which means that there is a significant influence on differences in doses of papaya seeds powder solution used against the death of Ae. aegypti larvaes. Kaffir lime peel contains essential oils that can be used as biological insecticides in DHF vector control.
\end{abstract}

Keywords: essential oils; kaffir lime peel; behavior; mortality; Aedes aegypti larvae

\section{Introduction}

Dengue fever is caused by dengue virus of the genus Flavivirus, family of Flaviviridae. This disease is transmitted through bites of the female mosquito Aedes aegypti. (Nisa et al, 2015) Dengue is endemic in 124 countries of the world and at least 4 billion people are at risk of this disease. (Yuliasih \& Mutiara, 2017). Dengue fever is not only increases in tropical and subtropical regions but has also spread in Europe (Kementerian Kesehatan RI, 2016). The World Health Organization (WHO) mentioned Indonesia as the country with the highest cases of dengue fever in Southeast Asia. (Nirma et al, 2015)

The number of dengue cases in 34 provinces in Indonesia in 2017 was 68,407. (Kementerian Kesehatan RI, 2018). While in 2016, there were as many as 202,314 patients and 1593 people died (Kementerian Kesehatan RI, 2017). Prevention of

\footnotetext{
*) Corresponding Author (Ririh Jatmi Wikandari)

E-mail: j.ririh@gmail.com
}

dengue fever is still prioritized in vector control because there are still no effective vaccines and antiviral drugs available. (Dias and Denise, 2014)

One way to control vector mosquitoes is to control the life cycle of mosquitoes at the pre-adult stage (larvae) (Inayati. N, M. Wiwin, 2013) (Yuliasih \& Mutiara, 2017). Mosquito larvae which breed in water are easier to be controlled compared to the adult stage because at the adult stage, they can fly to avoid insecticides (Ahbirami et al, 2014). The way to control mosquitoes is by killing mosquito larvae using larvacide. Larvaside which is commonly used in mosquito control programs is synthetic insecticides. (Yu et al, 2015)

The use of synthetic insecticides has several disadvantages. Long-term applications have adverse effects on human health, as well as the emergence of Ae. aegypti populations that is resistant to insecticides. (Mallick et al, 2015),(Monika N \& Waikabubak, 2016). To overcome this disadvantages, the biological 
insecticide can be used as an alternative in dengue vector control. Biological insecticide is derived from plants that contain chemical substances (bioactive) which are toxic to insects but easy to decompose (biodegradable) in nature so they do not pollute the environment and are relatively safe for humans.

Recently, many studies have found that plants have potentials for natural insecticides. (Rocha et al., 2015)'(RAJ et al, 2017)'(Pinto et al, 2016). Citrus family plants have potential as a natural insecticide. (Mya et al, 2015)'(Hamidah. \& Hebert, 2017). Kafir lime (Citrus hystrix) is one of the potential citrus plants. Part of kaffir lime skin is one part of the plant that is used as a natural insecticide. Kaffir lime peel is used as an insecticide because it has an active chemical content found in skin essential oils. (Sihombing et al., 2015)

The essential oil of kaffir lime peel shows larvicidal activity against larvae of Culex quinquefasciatus. (Poolprasert, Pama, Chammui, \& Thongchai, 2015) Methanol extract of kaffir lime leaves is also reported to have larvicidal activity against third instar of Ae. aegypti larvae. (Adrianto et al, 2014) Essential oils of kaffir lime peel show a repellant effect on Ae aegypti mosquitoes adult. (Soonwera, 2015) However, there is no information about the effect of kaffir lime peel essential oil on third instar of Ae. aegypti larvae. The purpose of this study is to identify the effect of kaffir lime peel essential oil on the behavior and mortality of Ae. aegypti larvae.

\section{Method}

This research is an experimental study, with a completely randomized design of three treatments and three replications using third instsar of Ae. aegypti larvae. Larvae were obtained from laboratory colonies from the results of $A e$. aegypti egg rearing originating from the Ciamis Sources Animal Disease Control Laboratory Loka Litbangkes. Aedes aegypti is commonly used in screening insecticide testing because it is usually less vulnerable and easy to colonize in laboratories. (WHO, 2005)

The material used in the study was the peel of kaffir lime fruit originating from Kuncen, Banguntapan Bantul, Yogyakarta. The peel of a kaffir lime fruit was then extracted for essential oils by distillation. The essential oil obtained was dissolved by tween 80 and then diluted with distilled water according to the concentration to be tested (10ppm, $10^{2} \mathrm{ppm}$ and $\left.10^{3} \mathrm{ppm}\right)$. A concentration of $10 \mathrm{ppm}$ was made by adding $1 \mu \mathrm{l}$ of essential oil with $99,999 \mu \mathrm{l}$ of distilled water, $10^{2} \mathrm{ppm}$ concentration $(10 \mu \mathrm{l}+99,990 \mu \mathrm{l}$ of distilled water) and concentration of $10^{3} \mathrm{ppm}$ $(100 \mu 1+99,900 \mu l$ of distilled water $)$.

The test was carried out at a temperature of $25 \pm 2^{\circ} \mathrm{C}, 80 \%$ humidity with each concentration in a glass vial containing 25 larvae at the final volume of $100 \mathrm{ml}$. The amount of replication in each concentration was 3 times replication. Larva mortality in each treatment was recorded after a 24-hour exposure. If the control mortality is between $5 \%-20 \%$, the mortality of the treatment group must be corrected by the Abbott formula: ( $\mathrm{x}-\mathrm{y})$ divided by (y) multiplied by 100; with $\mathrm{x}$ is the living larvae in the control group and $y$ is the living larvae in the treatment group. Data from all replications were collected for analysis. LC50 and LC90 values were calculated using Probit analysis. Larva behavior parameters were observed during the test period.

\section{Result and Discussion}

Behavior of Ae. aegypti larvae during exposure shows that control larvae actively moved in the water by making swimming movements forming a 'S' pattern. Movement of larvae exposed to kaffir lime peel essential oil at $10 \mathrm{ppm}$ and $10^{2} \mathrm{ppm}$ until the end of the 24 hour exposure period shows the same swimming movements controls such as movements forming the 'S' pattern movement on the surface, in the middle and at the bottom of the container. In larvae exposed to kaffir lime peel essential oil concentration of $10^{3} \mathrm{ppm}$, the frequency of larval movements decreased, larvae formed groups, they could not rise to the surface, and they kept moving at the base of the container even when touched after 1.5 hours.

Based on the results of observations of the third instar Ae larvae. aegypti, after 24 hours exposure to kaffir lime skin essential oil, there was no mortality in the control. Whereas larvae mortality was found at $10^{2} \mathrm{ppm}$ and $10^{3} \mathrm{ppm}$ at 5 and 22 respectively (Table 1 ). 
Jurnal Riset Kesehatan, 9 (1), 2020, 8 - 11

DOI: $10.31983 /$ jrk.v9i1.4953

Table 1. Mortality of Third Instar Ae. aegypti Larvae due to Exposure to Kaffir Lime Peel Essential Oil

\begin{tabular}{ccccccc}
\hline $\begin{array}{c}\text { Concentration } \\
\text { (ppm) }\end{array}$ & $\begin{array}{c}\text { Test larvae } \\
\text { (tail) }\end{array}$ & \multicolumn{3}{c}{$\begin{array}{c}\text { Mortality on } \\
\text { replication }\end{array}$} & Average & \% \\
\cline { 2 - 5 } & & $\mathbf{1}$ & $\mathbf{2}$ & $\mathbf{3}$ & & \\
\hline 0 (control) & 25 & 0 & 0 & 0 & 0 & 0 \\
10 & 25 & 0 & 0 & 0 & 0 & 0 \\
$10^{2}$ & 25 & 5 & 4 & 6 & 5 & 20 \\
$10^{3}$ & 25 & 22 & 23 & 21 & 22 & 88 \\
\hline
\end{tabular}

Log 10 from a concentration of $10 \mathrm{ppm}$ was $1,10^{2}$ ppm of 2 and $10^{3}$ of 3 (Table 2).

Table 2. Probit vs Log Concentration

\begin{tabular}{cccc}
\hline $\begin{array}{c}\text { concentration } \\
(\mathrm{ppm})\end{array}$ & $\begin{array}{c}\log 10 \\
\text { (concentrtion) }\end{array}$ & $\begin{array}{c}\% \\
\text { mortality }\end{array}$ & probit \\
\hline 10 & 1 & 0 & 0 \\
100 & 2 & 20 & 4,16 \\
1000 & 3 & 88 & 6,18 \\
\hline
\end{tabular}

LC50 was 263,552 ppm with a lower limit of $199,887 \mathrm{ppm}$ and an upper limit of $348,469 \mathrm{ppm}$ (Table 3).

Table 3. Probit Analysis Result

\begin{tabular}{ccccc}
\hline & \multicolumn{3}{c}{$95 \%$ Confidence Limit For } \\
& & \multicolumn{3}{c}{ Konsentrasi } \\
\cline { 3 - 5 } & Probability & e & $\begin{array}{c}\text { Eower } \\
\text { Bound }\end{array}$ & $\begin{array}{c}\text { Upper } \\
\text { Bound }\end{array}$ \\
\hline Probit & 0.500 & 263.552 & 199.887 & 348.469 \\
\hline
\end{tabular}

$\mathrm{p}$ value $<$ sig. $=0.05$, means that there is a significant influence on differences in doses of essential oil of kaffir lime peel used against the death of Ae. aegypti larvaes (Table 4).

Table 4. ANOVA Analysis

\begin{tabular}{lrrrrr}
\hline & $\begin{array}{c}\text { Sum of } \\
\text { squares }\end{array}$ & df & $\begin{array}{c}\text { Mean } \\
\text { squares }\end{array}$ & F & P value \\
\hline Between & & & & & \\
$\begin{array}{l}\text { Groups } \\
\text { Within }\end{array}$ & 980.25 & 3 & 326.75 & 653.5 & $6.7 \times 10^{-9}$ \\
Groups & 4 & 8 & 0.5 & & \\
Total & 984.25 & 11 & 89.47 & & \\
\hline
\end{tabular}

Essential oil consists of a mixture of major and minor chemical compounds. Kaffir lime peel essential oil contains chemical compounds namely limonene, 1,8-cineol, a-pinene, $\beta$-pinene, (-) - camphene, isobutylamide alkaloid pellitorine, myrcene, and linalool. All of these compounds are known to have larvicidal activity. (Rocha et al., 2015)' (Kelkenberg et al., 2015)' (Bedini et al., 2016)

Essential oil is difficult to dissolve in water, so in order to dissolve it, it is added with emulsifier/ emulsifier tween 80. Based on the results, the addition of tween 80 as an essential oil emulsifier, did not have an effect on larvae, which was evidenced by not finding larval mortality in the control. Larvae mortality is caused by essential oils of kaffir lime peel. This is in accordance with Fujiwaraa (2017) that giving tween 80 to controls does not cause larval death so that tween which can be informed 80 does not cause negative effects on Ae. aegypti larvae.

The movement of larvae exposed to kaffir lime peel essential oil concentration of $10^{3} \mathrm{ppm}$ until the end of the 24 hour exposure shows a decrease in movement. Larvae could not move up to the surface, they only moved at the base of the container. The results of this study were consistent with those reported by Sneha (Sneha \& Preet, 2016) that during the test, essential oils affected the test larvae which decreased the frequency of larval movements. Decreased frequency of larval movements is the first sign that a material has larvacidal properties (Torres et al., 2014)

The decrease in the frequency of larval movement is the effect of one of the compounds in kaffir lime peel essential oil namely monoterpene. Most essential oils of kaffir lime peel are monoterpene. Monoterpene has a larvacide effect by disrupting the nervous system of the larvae which, if it continues, will cause paralysis and eventually will make the larvae die. (Sulistiyani, 2015)

The biggest content of monoterpene kaffir lime is limonene. Limonene has a strong insecticidal activity and AchE inhibitory activity. (Gnankiné \& Imaël, 2017) AChE inhibition causes accumulation of acetylcholine in synapses, so that post-synaptic membranes are in a state of permanent stimulation, which results in ataxia 
which is a general lack of coordination in the neuromuscular system, and eventually causes death. (Botas et al., 2017)

Larvae mortality is caused by essential oils of kaffir lime peel. Oil can enter the body of Ae. aegypti mosquito larvae. It enters through the digestive tract and is absorbed by the intestinal wall. It then circulates with the hemolimp which will disrupt the body's metabolism so that it will lack of energy for its life activities which will cause the mosquito to spasm and eventually die. (Nirma et al., 2015)' (Sulistiyani, 2015)

The number of larval mortality increases with increasing concentration of essential oil of kaffir lime peel. This is in line with Pierre, (2014) and Ihemanma (2014) who stated that if the concenration is higher, the extract will have higher toxic levels so that there will be more larvae mortality.

\section{Conclusion and Sugestion}

The essential oil of kaffir lime peel affects the behavior of larvae and causes death of the third instar larvae Ae. aegypti. So it is necessary to do research using emulsifiers other than tween 80 to obtain the best formula for making larvacides which is practical for Dengue Fever vector control applications.

\section{Acknowledgements}

Thanks to the Ministry of Health of the Republic of Indonesia through the Health Human Resources Development and Empowerment Program which has provided scholarship funds and thanks also to those who have helped carry out the research.

\section{References}

Adrianto, H., Yotopranoto, S., \& Hamidah. (2014). Efektivitas Ekstrak Daun Jeruk Purut (Citrus hystrix), Jeruk Limau (Citrus amblycarpa), dan Jeruk Bali (Citrus maxima) terhadap Larva Aedes aegypti. Aspirator, 6(1), 1-6.

Ahbirami, R., Zuharah, W. F., Thiagaletchumi, M., Subramaniam, S., \& Sundarasekar, J. (2014). Larvicidal efficacy of different plant parts of railway creeper, ipomoea cairica extract against dengue vector mosquitoes, aedes albopictus (Diptera: Culicidae) and aedes aegypti (Diptera: Culicidae). Journal of Insect Science, 14(Isman 2006). https://doi.org/10.1093/jisesa/ieu042

Bedini, S., Flamini, G., Cosci, F., Ascrizzi, R.,
Benelli, G., \& Conti, B. (2016). Cannabis sativa and Humulus lupulus essential oils as novel control tools against the invasive mosquito Aedes albopictus and fresh water snail Physella acuta. Industrial Crops and Products, 85, 318-323. https://doi.org/10.1016/j.indcrop.2016.03 .008

Botas, G., Rodrigo, A., Fernanda, B., Jonatas, L., Raquel, S., Raimundo, N., \& Et, A. (2017). Baccharis reticularia DC. and Limonene Nanoemulsions: Promising Larvicidal Agents for Aedes aegypti (Diptera: Culicidae) Control. Molecules, 22, 1-14. https://doi.org/10.3390/molecules221119 90

Dias and Denise, F. (2014). Essential oils and their compounds as Aedes aegypti L. (Diptera: Culicidae) larvicides: Review. Parasitology Research, Vol. 113, pp. 565-592. https://doi.org/10.1007/s00436-013-36876

Fujiwaraa, G., Vinicius, A., Camila, F., Ricardo, A., Maria, M., Fernando, C., \& Et, A. (2017). Ecotoxicology and Environmental Safety Ecotoxicology and Environmental Safety. Ecotoxicology and Environmental Safety, 139(2017), 238-244. https://doi.org/x.doi.org/10.1016/j.ecoen v.2017.01.046

Gnankiné, O., \& Imaël, H. (2017). Essential Oils as an Alternative to Pyrethroids ' Resistance against Anopheles Species Complex Giles. Molecules, 22, 1-23. https://doi.org/10.3390/molecules221013 21

Hamidah., \& Hebert, A. (2017). Toxicity of Citrus mitis, Citrus aurantifolia, and Citrus maxima Leaf Extract Toward Mortality of Aedes aegypti Larvae ( Diptera: Culicidae ). The Veterinary Medicine International Conference, 41-47. https://doi.org/10.18502/kls.v3i6.1105

Ihemanma, C., Adindu, R., Kalu, M., \& Kalu, E. (2014). Laboratory evaluation of ethanolic extracts of citrus sinensis peels and piper guineense (seeds and leaves) on mosquito larvae. Journal of Environment and Human, 1(1), 19-24.

Inayati. N, M. Wiwin, E. Y. (2013). Ekstrak Biji Srikaya (Annona squamosa) sebagai Daya Bunuh Larva aAedes sp. Jurnal Riset Kesehaan, 2(2), 332-335.

Kelkenberg, M., Odman-Naresh, J., Muthukrishnan, S., \& Merzendorfer, $\mathrm{H}$. 
(2015). Chitin is a necessary component to maintain the barrier function of the peritrophic matrix in the insect midgut. Insect Biochemistry and Molecular Biology, 56, 21-28.

https://doi.org/10.1016/j.ibmb.2014.11.00 5

Kementerian Kesehatan RI. (2016). Infodatin: Pusat Data dan Informasi Kementerian Kesehatan RI. Jakarta.

Kementerian Kesehatan RI. (2017). Data dan Informasi Profil Kesehatan Indonesia Tahun 2016 (H. Boga, Yudianto., \& S. Tit, Eds.). Jakarta.

Kementerian Kesehatan RI. (2018). InfoDatin Situas Demam Berdarah Dengue. Journal of Vector Ecology, Vol. 31, pp. 71-78. https://doi.org/10.3376/1081-1710(2006)3 1[71:aomtva]2.0.co;2

Mallick, S., Banerjee, R., \& Chandra, G. (2015). Mosquito larvicidal potential of ethanol leaf extract of the plant, Annona reticulata L. against Aedes aegypti L. and Culex quinquefasciatus Say (Diptera: Culicidae). Journal of Mosquito Research, 5(19), 1-7. https://doi.org/10.5376/jmr.2015.05.0019

Monika N, R. W., \& Waikabubak. (2016). Larvasida Hayati Yang Digunakan Dalam Upaya Pengendalian Vektor Penyakit Demam Berdarah di Indonesia. SEL, 3(1), 31-40.

Mya, M. M., Aye, Y. Y., Oo, A. W., \& Saxena, R. K. (2015). Effect of Citrus hystrix DC Leaves Ethanol Extract on Larvae of Aedes aegypti. Journal of Biological Engineering Research and Review, 2(2), 1-6. Retrieved from www.biologicalengineering.in/Archive

Nirma, Andi, S., Hasbi, I., \& Munawir, A. (2015). Efektivitas Larvasida Ekstrak Kulit Buah Jeruk Nipis ( Citrus aurantifolia ) Dalam Membunuh Jentik Nyamuk Aedes sp ( Studi di Daerah Epidemi DBD di Wilayah Kerja. Higiene, 1(2), 2017.

Nisa K, Firdaus, Ovi F, Ahmadi, H. (2015). Uji Efektifitas Ekstrak Biji dan Daun Mengkudu (Morinda Citrifolia L.) sebagai Larvasida Aedes sp. Badan Penelitian Dan Pengembangan Kesehatan, 2(2), 44. Retrieved from

http:/ / ejournal.litbang.depkes.go.id/inde x.php/sel/article/download/4636/4142

Pierre, S., EC Okechukwu, Y Lame, N. N. (2014). Larvicidal and Pupicidal Toxicities of Plectranthus glandulosus and Callistemon rigidus Leaf Essential Oils against Three Mosquito Species. Journal of Mosquito Research, 4(2), 5-14. https://doi.org/10.5376/jmr.2014.04.0002

Pinto CC, Jane ESAM, Sônia MC, Diego SMS, Cleia RS, H. S. (2016). Chemical composition and larvicidal activity against Aedes aegypti of essential oils from Croton zehntneri. Boletín Latinoamericano y Del Caribe de Plantas Medicinales y Aromáticas, 15(2), 122-127. https://doi.org/10.3390/molecules150857 34

Poolprasert, P., Pama, W., Chammui, Y., \& Thongchai, W. (2015). Screening of Medical Plants Extracts for Larvicidal Activity against Culex quinquefasciatus ( Diptera: Culicidae). The International Conference on Herbal and Traditional Medicine, (Htm), 228-230.

RAJ, G. A., Chandrasekaran, M., Venkatesalu, V., \& Jegan, S. (2017). c ALATUM (WALL . EX WT . E ARN ) Swingle Against Aedes aegypti, Anpheles stephensi and Culex quinquefasciatus (Dptera: Culicidae). 4(5), 5-8.

Rocha, D., Olivia, M., Maria, T., Ana, C., Manuel, D., \& Chtistina, M. (2015). Larvicidal Activity against Aedes aegypti of Foeniculum vulgare Essential Oils from Portugal and Cape Verde. Natural Product Communications, 10(4), 677-682. https://doi.org/10.1073/pnas.0703993104

Sihombing, J. R., Dharma, A., Chaidir, Z., Almahdy, Fachrial, E., \& Munaf, E. (2015). Phytochemical screening and antioxidant activities of 31 fruit peel extract from Sumatera, Indonesia. Journal of Chemical and Pharmaceutical Research, 7(11).

Sneha, A., \& Preet, S. (2016). Impact of Sublethal Conventional and Biorational Larvicidal Stress on Fitness Status in Nutritionally Challenged Aedes aegypti Larvae. International Journal of Mosquito Research, 3(1), 39-46.

Soonwera, M. *. (2015). Efficacy of Essential Oils from Citrus plants against Mosquito vectors Aedes aegypti (Linn.) and Culex quinquefasciatus (Say). Internatioal Journal of Agricultural Technology, 11(3), 669-681. Retrieved from http:/ / www.ijat-aatsea.com

Sulistiyani, A. (2015). Effectiveness of Essential Oil as Larvacide on Aedes aegypti. Jurnal Majority, 4(3), 22-28.

Torres, S., Nadine, L., Vitor, P., Maria, I., Leucio, 
C., \& Valdemiro, A. (2014). Cumulative Mortality of Aedes aegypti Larvae Treated with Compounds. Rev Saúde Pública, 48(3), 445-450.

https://doi.org/10.1590/S0034-8910.20140 48005022

WHO. (2005). Guidelines for laboratory and field testing of mosquito larvicides. In World Health Organization. https://doi.org/Ref: WHO/CDS/WHOPES/GCDPP/2005.11

Yu, K., Wong, C., Ahmad, R., \& Jantan, I. (2015). Larvicidal activity, inhibition effect on development, histopathological alteration and morphological aberation induced by seaweed extracts in Aedes aegypti (Diptera:
Culicidae). Asian Pacific Journal of Tropical Medicine, $\quad 8(12), \quad$ 1006-1012. https://doi.org/10.1016/j.apjtm.2015.11.0 11

Yuliasih, Y., \& Mutiara, W. (2017). Aktivitas Larvasida Berbagai Pelarut pada Ekstrak Biji Kayu Besi Pantai ( Pongamia pinnata ) terhadap Mortalitas Larva Aedes spp. Larvicidal Activity of Various Solvents of Pongamia pinnata Seed Extract on the Mortality of Aedes spp . Balaba, 13(2), 125-132.

https://doi.org/https://doi.org/10.22435 /blb.V13i2.5807.125-132 